\title{
CHROMOSOMAL ANOMALIES OF PREIMPLANTATION MOUSE EMBRYOS IN RELATION TO MATERNAL AGE
}

\author{
R. G. GOSDEN \\ Physiological Laboratory, Downing Street, Cambridge CB2 3EG
}

(Received 30th Fanuary 1973)

\begin{abstract}
Summary. A total of 168 air-dried chromosome preparations of preimplantation mouse embryos were examined. The embryos were taken from $\mathrm{CBA} / \mathrm{H}-\mathrm{T} 6$ female mice of 1 to 12 months of age. The majority in all age groups were found to be diploid. The incidence of triploidembryos was independent of, and that of other hyperdiploid embryos dependent on, maternal age.
\end{abstract}

It is well known that increasing maternal age in animals is associated with reduced fertility. In man, there is a corresponding increase in the proportion of certain trisomic offspring, notably those with Down's syndrome, born to older mothers (Roberts, 1970). Finn (1962) reported that the diminished fecundity of old female mice is mainly due to the resorption of implanted embryos, but it has not yet been conclusively shown whether it is the embryo or the uterine environment which is deficient. Studies of spontaneous human abortuses have demonstrated that this reproductive failure is often associated with chromosomally abnormal conceptuses (Carr, 1972). Accordingly, in this study the incidence of chromosomally abnormal embryos from ageing female mice has been determined before postimplantation losses occur.

Inbred mice of the CBA/H-T6 strain were chosen for this study because of their short reproductive life-span (10 to 12 months in our colony). Female mice of more than 8 months old were regarded as an old group because the mean litter size declines steadily after this age (Text-fig. 1). This decline has been found to be a result of an increased failure of implantation as well as a failure of subsequent development (R. G. Gosden, in preparation). Forty-four female mice aged 1 to 12 months were mated with young fertile males of the same strain. Ovulation was induced in immature females with 3 i.u. PMSG followed by 1 i.u. HCG $44 \mathrm{hr}$ later. Mice were injected with $1 \mu \mathrm{g}$ Colcemid (Ciba)/g body weight $3 \frac{1}{2}$ days after coitus to arrest mitosis. The animals were killed approximately $2 \mathrm{hr}$ later. The uterine cornua were each dissected free, blotted and flushed with M199 medium containing $10 \%$ inactivated fetal calf serum, 5 to $8 \%$ phosphate buffer $(\mathrm{pH} 7 \cdot 1$ ) and 100 i.u. penicillin $/ \mathrm{ml}$. The oviducts were also flushed with medium if the yield of ova fell much below the expected number judging from CL of pregnancy counts. The ova were counted and scored for their developmental stage. Chromosome preparations of morulae and 
blastocysts were made by an air-drying technique (Tarkowski, 1966), and these were later stained with lactic acetic orcein as described by Vickers (1967). Each preparation was examined with $\times 1000$ phase-contrast microscopy and chromosomes were drawn, photographed and counted as 'blinds'. No attempt was made to identify deleted or supplementary chromosomes or the sex of the embryos. The number of nuclei for each embryo was noted; metaphase plates were counted as one nucleus.

A total of 168 out of 332 preparations yielded chromosome spreads which could be counted precisely or approximately ( \pm 2 chromosomes). The per-

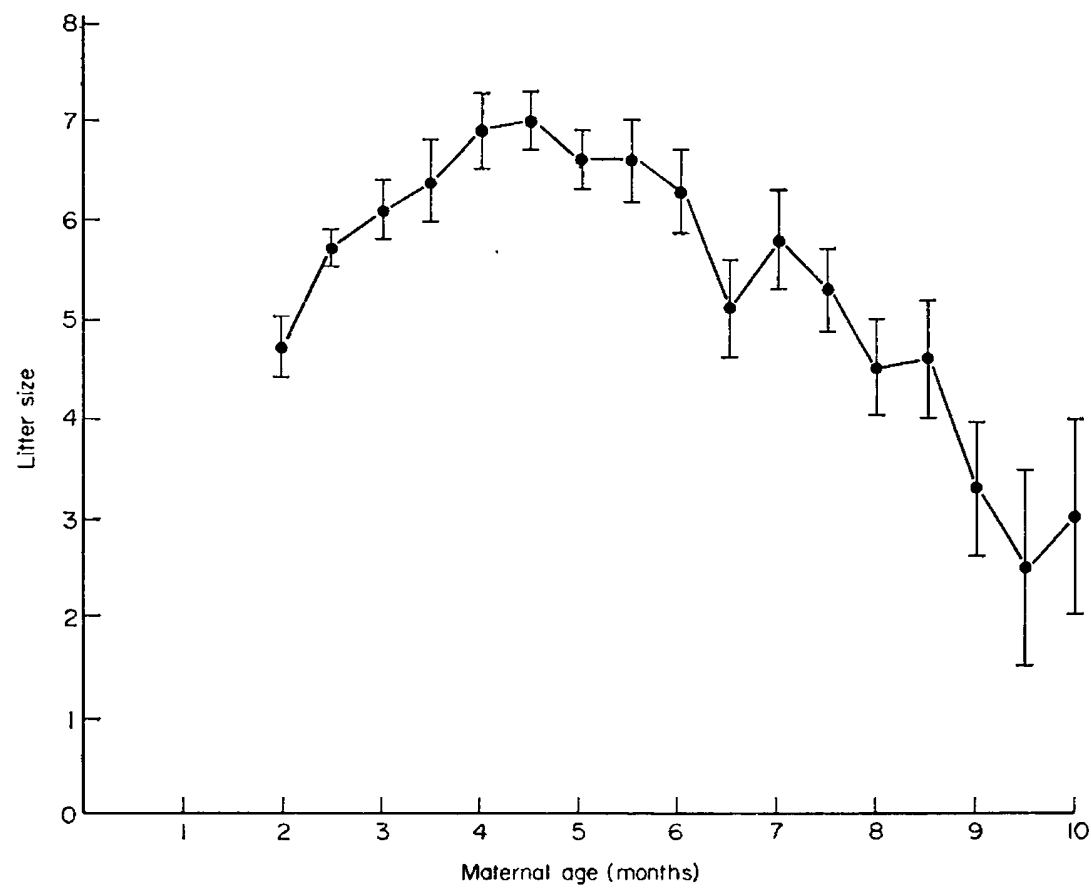

TEXT-FIG. 1. Long-term reproductive performance of sixty-four GBA/H-T6 female mice over a 2-year period. Maternal age is related to mean litter size \pm S.E.M.

centage recovery of morulae and blastocysts/number of CL of pregnancy was high for both adult groups $(76 \%$ and $74 \%$ for young and old groups, respectively) which suggested that preimplantation losses were small. The results of this study (Table 1) showed that the majority of embryos, even from the oldest females, had a normal diploid complement ( $2 n=40$ chromosomes). The agerelated decline in litter size cannot therefore be primarily due to visible chromosomal disorders.

In those preparations where precise counts of chromosome number were possible (one to five metaphase plates/embryo were counted), they were tabulated according to whether they were diploid, hyperdiploid or polyploid (Table 1). Embryos which had hypodiploid complements or overlapping chromosomes, so that precise counts could not be made with confidence, were included in a separate category if they had $2 n \pm 2$ chromosomes. The ploidy of these groups could be determined. 
The incidence of all hyperdiploids and polyploids was non-significantly different between age groups. The incidence of triploidy did not differ significantly between the groups and, overall, it was $4 \cdot 2 \%$. This result may suggest, if the claim of Vickers (1969) that delayed fertilization causes increased triploidy is well founded, that there is no delayed fertilization in the aged mouse. Two tetraploid embryos were recovered, one from an immature and the other from an 8-month-old female. One trisomic embryo occurred in the immature group $(3.4 \%)$, which is perhaps not surprising because ovulation had been artificially induced. Embryos with 41 or 42 chromosomes made up $10.5 \%$ of embryos from old mothers, but there were none found in the 2- to 7 -month-old adults. The differences between age groups in the incidence of

Table 1. Chromosomal analysis of $1683 \frac{1}{2}$-day mouse embryos from mothers of different ages

\begin{tabular}{|c|c|c|c|c|c|c|c|c|c|}
\hline \multirow{2}{*}{$\begin{array}{c}\text { Maternal age } \\
\text { (months) }\end{array}$} & \multirow{2}{*}{$\begin{array}{l}\text { No. of } \\
\text { females }\end{array}$} & \multirow{2}{*}{$\begin{array}{c}\text { Diploid } \\
(2 \mathrm{n}=40)\end{array}$} & \multirow{2}{*}{$\begin{array}{c}\text { Diploid } \dagger \\
( \pm 2)\end{array}$} & \multicolumn{4}{|c|}{$\begin{array}{c}\text { Hyperdiploid and } \\
\text { polyploid }\end{array}$} & \multirow{2}{*}{$\begin{array}{l}\text { Total no. } \\
\text { of entbryos }\end{array}$} & \multirow{2}{*}{$\begin{array}{c}\% \text { anomalous } \\
\text { embryos }\end{array}$} \\
\hline & & & & $2 n+1$ & $2 n+2$ & $3 n$ & $4 n$ & & \\
\hline $\begin{array}{c}1 \\
\text { (immature) }\end{array}$ & 8 & 28 & 15 & 1 & - & 2 & 1 & 47 & $8.5 \%$ \\
\hline $\begin{array}{c}2 \text { to } 7 \\
\text { (young adult) }\end{array}$ & 20 & 39 & 21 & - & - & 3 & - & 63 & $4.8 \%$ \\
\hline 8 to 12 & 16 & 34 & 17 & $3^{*}$ & $1^{*}$ & $2 \ddagger$ & 1 & 58 & $12.1 \%$ \\
\hline
\end{tabular}

* Significantly different when compared to 2 to 7 month group $(P=0.0545)$ and to 1 to 7 month group $(P=0.0495)$.

$\dagger$ Some overlapping of chromosomes made precise counts impossible.

$\$$ Not significantly different when compared to younger groups.

these embryos reached statistical significance by Fisher's exact test of probability $(P=0.0545$ when comparing old with young adult group; $P=0.0495$ when comparing old with all others). The mean number of nuclei (and therefore the number of cells) in embryos from young adults $(26 \cdot 6)$ and old adults $(24.2)$ was significantly different $\left(F_{1,123}=4.085, P<0 \cdot 05\right)$. This difference may be attributed either to a later time of ovulation or to a retarded rate of cleavage in the older females.

The results of the reciprocal embryo transplantation experiments of Talbert \& Krohn (1966) are in general agreement with the results of this study. They found no reduced viability of embryos from older female mice compared to young controls, but there was a small increase in the proportion of morphologically abnormal ova from old mothers. Recently, Yamamoto, Endo \& Watanabe (1973) reported that the proportion of aneuploid embryos in mice was dependent on maternal age, whereas the proportion of triploid embryos was not. These findings seem to be in agreement with those of the present study although it is not possible to tell from the data of Yamamoto et al. (1973) how

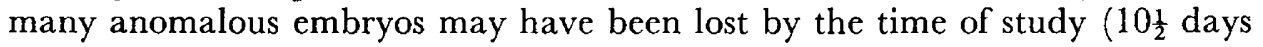
post coitum). Henderson \& Edwards (1968) reported an age-related increase in the incidence of univalents and decrease in chiasma frequency in mouse oocytes at diakinesis. They proposed that the probability of an abnormal egg 
being shed at ovulation was greater in the older mother and that this pattern was laid down at oogenesis. While the results reported here do not suggest that chromosomal anomalies are the major cause of infertility in older mothers, the hypothesis of Henderson \& Edwards (1968) is a possible explanation for the occurrence of those trisomic embryos which are found. It seems unlikely that any of these abnormal embryos would have survived to term in view of the failure of Goodlin (1965) to find any evidence of increased aneupoloidy in newborn mice with maternal age.

I would like to thank Dr R. G. Edwards, Dr R. L. Gardner and Dr M. H. Kaufman for helpful advice and discussion. This study was carried out during the tenure of a Medical Research Council Scholarship; working expenses were defrayed by a grant from the Ford Foundation to Professor C. R. Austin.

\section{REFERENCES}

Carr, D. H. (1972) Chromosomal anomalies in human foetuses. Res. Reprod. 4, (2) 3.

FinN, C. A. (1962) Embryonic death in aged mice. Nature, Lond. 194, 499.

Goodlin, R. C. (1965) Non-disjunction and maternal age in the mouse. F. Reprod. Fert. $9,355$.

Henderson, S. A. \& Edwards, R. G. (1968) Chiasma frequency and maternal age in mammals. Nature, Lond. 218, 22.

Roberts, J. A. F. (1970) Chromosome abnormalities. In: An Introduction to Medical Genetics, p. 167. Oxford University Press, London.

Talbert, G. B. \& Krohn, P. L. (1966) Effect of maternal age on viability of ova and uterine support of pregnancy in mice. 7. Reprod. Fert. 11, 399.

TARkowski, A. K. (1966) An air-drying method for chromosome preparations from mouse eggs. Cytogenetics, 5, 394.

Vickers, A. D. (1967) A direct measurement of the sex ratio in mouse blastocysts. F. Reprod. Fert. 13, 375.

Vickers, A. D. (1969) Delayed fertilization and chromosomal anomalies in mouse embryos. $\mathcal{J}$. Reprod. Fert. 20, 69.

Yamamoto, M., Endo, A. \& Watanabe, G. (1973) Maternal age dependence of chromosome anomalies. Nature, Lond. 241, 141. 